\title{
Impact of water hardness on energy consumption of geyser heating elements
}

\author{
Lerato Lethea ${ }^{1 *}$ \\ 'Demand Management Centre of Expertise, Eskom Research, Testing, and Development, Private Bag X40175, Cleveland, 2022, South Africa
}

\begin{abstract}
South Africa is an electricity-stressed country with a growing energy demand. Globally, hot water appliances are major consumers of electricity. Poor water quality for domestic purposes is a concern that may affect the efficiency of hot water appliances. Therefore, the Eskom Research, Testing, and Development Business Unit embarked on a study to examine total water hardness as a chemical parameter that may impact the power consumption of electrical geyser heating elements. An accelerated scaling method was developed to lime-scale the geyser heating elements for about 2 to 3 months. In addition, the geyser heating elements were tested with and without electronic descaler technology. The results showed that the accelerated scaling method developed for shortening the scaling time of geyser heating elements was successful. Furthermore, the results proved that scale formation of $1.5 \mathrm{~kW}$ and $3 \mathrm{~kW}$ geyser heating elements due to high total water hardness increased the power consumption by approximately $4 \%$ to $12 \%$. This paper also presents energy-efficient electronic descaler technology as an alternative treatment of scaling for geyser heating elements.
\end{abstract}

Keywords: electronic descaler technology, energy consumption, geyser heating element, scaling, total water hardness

\section{INTRODUCTION}

Worldwide, population growth is continuously increasing energy demand. The main consumer of electrical energy globally is water heating (Ibrahim et al., 2014). The total domestic energy consumption percentage of water heating for the USA, Europe, Canada, Australia, Mexico, China, and South Africa is $11 \%, 14 \%, 22 \%, 25 \%, 29 \%, 27 \%$, and $32 \%$, respectively (Ibrahim et al., 2014). South Africa, in particular, was electricity stressed in the past decade, and this led to the introduction of load shedding by Eskom. The impact of water quality on hot water technologies has been studied since the $1940 \mathrm{~s}$ (Stickford et al., 1984) and includes work by Arunchala (2011), Dobersek and Goricanec (2007) and Brazeau and Edwards (2011). In particular, the effect of scaling on energy efficiency has been researched by Widder and Baechler (2013).

The power industry is exploring treatment technologies that reduce scale deposit formation caused by high mineral content in water (Dobersek and Goricanec, 2007). Dobersek and Goricanec (2014) explain that scale deposits in hard water are due to the decrease in solubility of calcium carbonate with increasing temperature. Subsequently, energy is lost because of the precipitated scale with very low thermal conductivity on the heat-transfer surfaces (Dobersek and Goricanec, 2014). Dobersek and Goricanec (2014) showed that energy consumption of electrical heaters increased by more than $15 \%$ as a result of scale deposits of a $1 \mathrm{~mm}$ layer. The focus of the research presented in this paper was to study the impact of total water hardness on the power consumption of South African residential geyser heating elements with a developed accelerated scaling method.

\footnotetext{
To whom all correspondence should be addressed.

e-mail: Lerato.Lethea@eskom.co.za

Received 25 July 2017; accepted in revised form 9 October 2017
}

\section{Background}

Geysers are pressurised vessels used to heat and supply hot water for domestic and industrial purposes. A thermostat is a component of a geyser used to control the temperature of the water being heated. The heating element turns on when the temperature of the water drops below the set point of the thermostat and will turn off to prevent the water from overheating. Residential geysers are usually equipped with a $1.5,2$, or $3 \mathrm{~kW}$ heating element in a 150 or $200 \mathrm{~L}$ water tank (Catherine et al., 2012). The materials of construction for heating elements include steel, stainless steel, aluminium, copper, fluoropolymer, brass, iron, nickel alloy, and polyimide (Gouws and Le Roux, 2012). Arunchala (2011) indicated that the performance of a geyser may deteriorate within 5 to 12 years of its installation. Performance deterioration factors may include the manufacture of the geyser, operating conditions, water quality, and inadequate maintenance (Arunchala, 2011).

Total water hardness is expressed as the concentration of calcium carbonate that is equivalent to the total concentration of all multivalent ions in a water sample. Ca and $\mathrm{Mg}$ ions dominate metal ion concentrations and are the main contributors to water hardness (Skoog et al., 2014). Additional contributors include Al, Zn, Ba, Fe, Sr, and Mn (Sengupta, 2013). Water hardness salt types are provided in Table 1 (Sengupta, 2013). Carbonate hardness is formed by the carbonate, bicarbonate, and hydroxides anions that result in alkalinity (Sengupta, 2013). Alkalinity is defined as the capacity to neutralise acid (De Zuane, 1997). Hydroxide minerals have the ability to neutralise acids, and hence are grouped in the carbonate hardness class (Sengupta, 2013, Table 1). Carbonate hardness can be removed simply by boiling the water (Sengupta, 2013). In comparison, non-carbonate hardness is formed by anions such as chlorides and sulphates (Widder and Baechler, 2013) and the scale deposits cannot be broken down by boiling the water (Sengupta, 2013). 
Total water hardness determination is important because precipitation of carbonate minerals may occur on heating the water, ultimately clogging pipes and boilers (Skoog et al., 2014). Scale formation result from the bicarbonate ion breakdown, as shown in Eq. 1 (Antony et al., 2011). High pH and alkaline conditions also promote precipitation of magnesium hydroxide, as shown in Eq. 2 (Hasson et al., 2010). The mineral content of water can be further classified as soft, moderately hard, hard, and very hard (Sengupta, 2013, Table 2). The sources of water hardness include geological minerals such as limestone and dolomite (Sengupta, 2013).

$$
\begin{gathered}
\mathrm{Ca}^{2+}+\mathrm{HCO}_{3}^{-}+\mathrm{OH}^{-} \rightarrow \mathrm{CaCO}_{3}+\mathrm{H}_{2} \mathrm{O} \\
\mathrm{Mg}^{2+}+2 \mathrm{OH}^{-} \rightarrow \mathrm{MgOH}_{2}
\end{gathered}
$$

Numerous water indices are used to predict the scaling and corrosion occurrence resulting from the water. These indices include the Langelier saturation index (LSI), Ryznar stability

TABLE 1

Water hardness salt types (source: Sengupta, 2013)

\begin{tabular}{|l|l|}
\hline Carbonate hardness compounds & $\begin{array}{l}\text { Non-carbonate hardness } \\
\text { compounds }\end{array}$ \\
\hline $\begin{array}{l}\text { Calcium carbonate } \\
\left.\mathrm{CaCO}_{3}\right)\end{array}$ & $\begin{array}{l}\text { Calcium sulphate } \\
\left(\mathrm{CaSO}_{4}\right)\end{array}$ \\
\hline $\begin{array}{l}\text { Magnesium carbonate } \\
\left(\mathrm{MgCO}_{3}\right)\end{array}$ & $\begin{array}{l}\text { Magnesium sulphate } \\
\left(\mathrm{MgSO}_{4}\right)\end{array}$ \\
\hline $\begin{array}{l}\mathrm{Calcium} \mathrm{bicarbonate} \\
\left(\mathrm{Ca}\left(\mathrm{HCO}_{3}\right)_{2}\right)\end{array}$ & $\begin{array}{l}\text { Calcium chloride } \\
\left(\mathrm{CaCl}_{2}\right)\end{array}$ \\
\hline $\begin{array}{l}\mathrm{Magnesium} \text { bicarbonate } \\
\left(\mathrm{Mg}\left(\mathrm{HCO}_{3}\right)_{2}\right)\end{array}$ & $\begin{array}{l}\mathrm{Magnesium} \text { chloride } \\
\left(\mathrm{MgCl}_{2}\right)\end{array}$ \\
\hline $\begin{array}{l}\mathrm{Calcium} \mathrm{hydroxide} \\
\left(\mathrm{Ca}(\mathrm{OH})_{2}\right)\end{array}$ & \\
\hline $\begin{array}{l}\mathrm{Magnesium} \text { hydroxide } \\
\left(\mathrm{Mg}(\mathrm{OH})_{2}\right)\end{array}$ & \\
\hline
\end{tabular}

TABLE 2

Water hardness classification (source: Sengupta, 2013)

\begin{tabular}{|l|c|}
\hline Degree of water hardness & $\begin{array}{l}\text { Dissolved concentration of calcium } \\
\text { and magnesium (mg/L) as } \mathrm{CaCO}_{3}\end{array}$ \\
\hline Soft & $<60$ \\
\hline Moderately hard & 61 to 120 \\
\hline Hard & 121 to 180 \\
\hline Very hard & $>180$ \\
\hline
\end{tabular}

index (RSI), Puckorius scaling index (PSI), Larson-Skold index (LS), and aggressive index (AI) (Shams et al., 2012). The LSI is the most widely used indicator of water scale potential, calculated using $\mathrm{pH}$ as the main variable (Saifelnasr et al., 2013). The LSI calculation takes into consideration the alkalinity $(\mathrm{mg} / \mathrm{L}$ as $\mathrm{CaCO}_{3}$ ), the calcium hardness $\left(\mathrm{mg} / \mathrm{L}\right.$ as $\left.\mathrm{CaCO}_{3}\right)$, the total dissolved solids (mg/L TDS), actual $\mathrm{pH}$, and temperature $\left({ }^{\circ} \mathrm{C}\right)$ of water. The equations of the LSI, RSI, and PSI and the resulting water condition are given in Table 3 , where $\mathrm{pHs}$ represents the saturation $\mathrm{pH}$. The PSI is obtained by calculating the equilibrium $\mathrm{pH}\left(\mathrm{pH}_{\mathrm{eq}}\right)$ using Eq. 3 (Saifelnasr et al., 2013).

$$
p H_{e q}=1.465 \times \log _{10}[\text { Alkalinity }]+4.54
$$

Treatment solutions that reduce water hardness scaling include chemical processes, electrochemical processes, and nanofiltration. Ras and Ghizellaoui (2012) applied potassium hydrogen phosphate $\left(\mathrm{K}_{2} \mathrm{HPO}_{4}\right)$ and potassium phosphate $\left(\mathrm{K}_{3} \mathrm{PO}_{4}\right)$ scale inhibitors to reduce calcium carbonate $\left(\mathrm{CaCO}_{3}\right)$ scale formation in Hamma water. These scale inhibitors blocked the growth sites of $\mathrm{CaCO}_{3}$ forming scale deposits (Ras and Ghizellaoui, 2012). In this study, the objectives were, therefore: (i) to develop a scaling acceleration method to shorten the test times for scaling the geyser heating element, (ii) to investigate the impact of scaling deposits due to total water hardness on energy consumption of geyser heating elements, and (iii) to test electronic descaler technology with the accelerated scaling method of geyser heating elements.

\section{MATERIALS AND METHODS}

Straight-shaped geyser heating elements of 1.5 and $2 \mathrm{~kW}$ with copper, coated with nickel, were the selected samples for this research. Twenty-litre high-density polyethylene (HDPE) heater buckets were constructed for testing of the geyser heating elements. Visual examination of all water buckets for geyser heating elements was done before testing. All experiments were performed at the $\mathrm{H} 2 \mathrm{O}$ Science Laboratory under the Demand Management Centre of Expertise in the Eskom Research, Testing, and Development Business Unit. The laboratory room temperature was maintained between $19^{\circ} \mathrm{C}$ and $21^{\circ} \mathrm{C}$. Close-view pictures of the geyser heating elements tested are shown in Fig. 1.

\section{Water hardness meters and indicators}

An EC-1385 meter tester was used to test the laboratory water before preparation of hard-water salt solutions. The EC-1385 meter is a three-in-one parameter water quality tester that

\begin{tabular}{|l|c|c|c|}
\hline \multicolumn{2}{|c|}{ Water stability indices (source: Shams et al., 2012) } \\
\hline \multirow{2}{*}{ Index } & Equation & Index value & Water condition \\
\hline \multirow{3}{*}{ Langelier saturation index } & \multirow{3}{*}{ LSI $=\mathrm{pHs}-\mathrm{pH}$} & $\mathrm{LSI}>0$ & Supersaturated; tends to precipitate $\mathrm{CaCO}_{3}$ \\
\cline { 3 - 4 } & & $\mathrm{LSI}=0$ & Saturated; $\mathrm{CaCO}_{3}$ is in equilibrium \\
\cline { 3 - 4 } & \multirow{3}{*}{ Ryznar stability index } & $\mathrm{LSI}<0$ & Undersaturated; tends to dissolve solid $\mathrm{CaCO}_{3}$ \\
\hline \multirow{2}{*}{ RSI $=2 \mathrm{pHs}-\mathrm{pH}$} & $\mathrm{RSI}<6$ & Supersaturated; tends to precipitate $\mathrm{CaCO}_{3}$ \\
\cline { 3 - 4 } & & $6<\mathrm{RSI}<7$ & Saturated; $\mathrm{CaCO}_{3}$ is in equilibrium \\
\cline { 3 - 4 } & & $\mathrm{RSI}>7$ & Undersaturated; tends to dissolve solid $\mathrm{CaCO}$ \\
\hline \multirow{2}{*}{ Puckorius scaling index } & \multirow{2}{*}{$\mathrm{PSI}=2 \mathrm{pHs}-\mathrm{pH}{ }_{\mathrm{eq}}$} & $\mathrm{PSI}<6$ & Scaling is unlikely to occur \\
\cline { 3 - 4 } & & $\mathrm{PSI}>7$ & Likely to dissolve scale \\
\hline
\end{tabular}



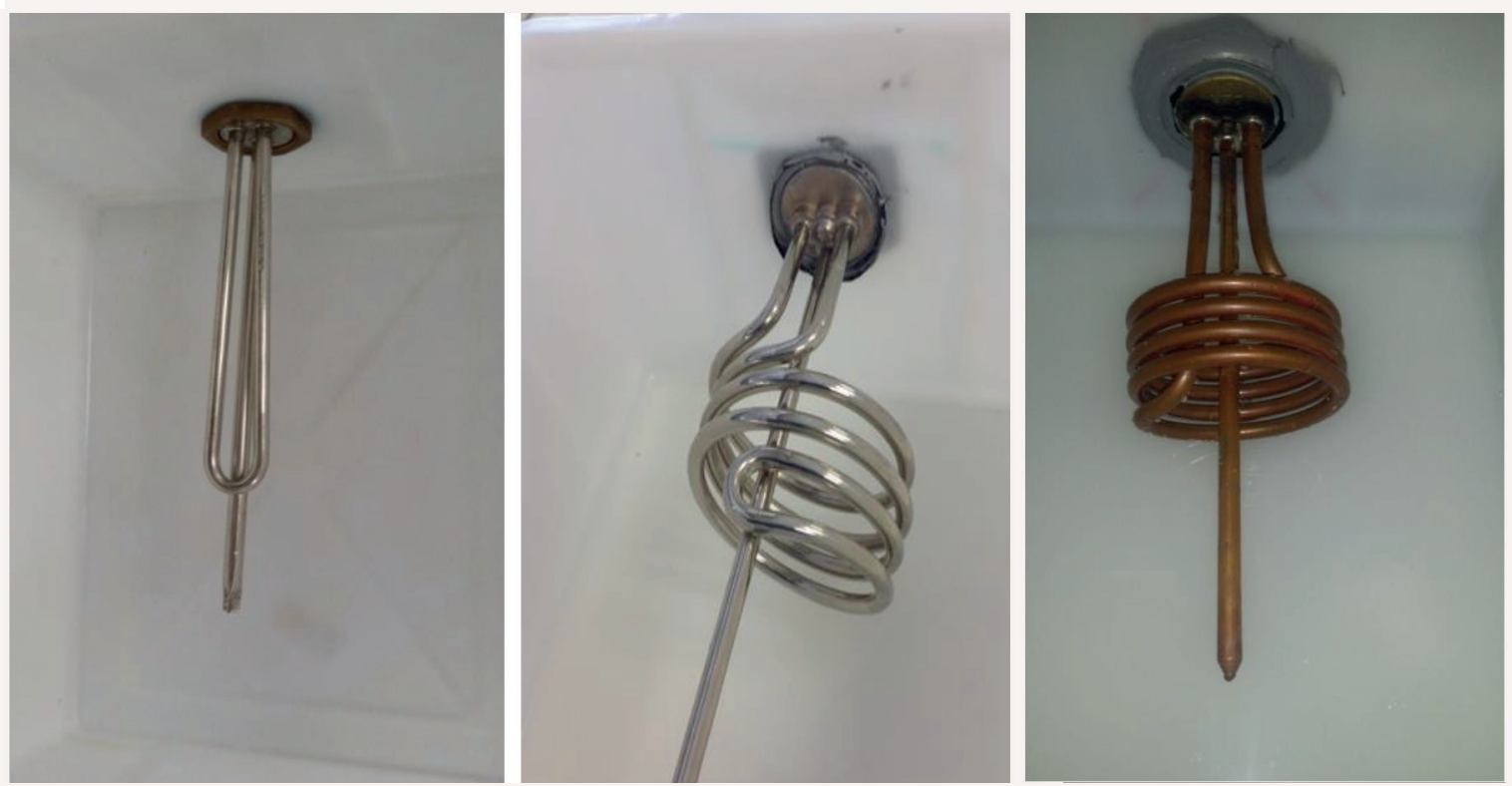

Figure 1

New $1.5 \mathrm{~kW}$ and $3 \mathrm{~kW}$ geyser heating elements

TABLE 4

Saline water classification (source: Reif and Alhalabi, 2015)

\begin{tabular}{|l|c|}
\hline Water class & Total dissolved solids (mg/L) \\
\hline Fresh water & $<500 \mathrm{mg} / \mathrm{L}$ TDS \\
\hline Slightly saline water & 500 to $1500 \mathrm{mg} / \mathrm{L}$ TDS \\
\hline Moderately saline water & 1500 to $7000 \mathrm{mg} / \mathrm{L}$ TDS \\
\hline Highly saline water & 7000 to $15000 \mathrm{mg} / \mathrm{L}$ TDS \\
\hline Very highly saline water & 15000 to $35000 \mathrm{mg} / \mathrm{L}$ TDS \\
\hline Brine water & $>35000 \mathrm{mg} / \mathrm{L}$ TDS \\
\hline
\end{tabular}

measures the electrical conductivity (EC), total dissolved solids (TDS), and the conductivity factor. Natural water usually contains dissolved ion salts, which provide a pathway for the flow of electrons through the solution, called electrical conductivity (Gopalan et al., 2008). The conductivity factor of dissolved salts in solution is a measure of the activity of the charged particles related to their concentration by a factor (Skoog et al., 2014). The term 'total dissolved solids' (TDS) refers to the wide variety of inorganic salts and organic matter that are dissolved in the water (Gopalan et al., 2008). A water hardness test strip was also used for water hardness testing of the tap water at the laboratory, reported as $\mathrm{mg} / \mathrm{L}$ $\mathrm{CaCO}_{3}$. This water hardness test involved the immersion of a test strip with 4 small square coloured fields in a $100 \mathrm{~mL}$ water sample. The test strip was immersed in the tap water sample for approximately a minute, until the colour chart results appeared. The results of a water hardness test strip depend on the concentration of the total water hardness of the water sample.

\section{Preparation of salt solutions}

The aim of developing the scaling acceleration method was to prepare salt solutions that could be classified as moderately saline water with a TDS between 1500 and $7000 \mathrm{mg} / \mathrm{L}$, or highly saline water with a TDS between 7000 and $15000 \mathrm{mg} / \mathrm{L}$. The classification of saline water based on TDS $(\mathrm{mg} / \mathrm{L})$ is given in Table 4 . The four salt types that were used to prepare the salt solution were calcium carbonate $\left(\mathrm{CaCO}_{3}\right)$, calcium sulphate $\left(\mathrm{CaSO}_{4} \cdot 2 \mathrm{H}_{2} \mathrm{O}\right)$, magnesium chloride hexahydrate $\left(\mathrm{MgCl}_{2} \cdot 6 \mathrm{H}_{2} \mathrm{O}\right)$, and magnesium sulphate $\left(\mathrm{MgSO}_{4} \cdot 7 \mathrm{H}_{2} \mathrm{O}\right)$. These salts contribute to water hardness, resulting in scale formation, as shown in Table 1 . This test method is laboratory developed. About $35 \mathrm{~g}$ of each salt was required to achieve a high hardness of water, made up to $20 \mathrm{~L}$ of tap water, to prepare the first salt solution. In order to prepare Solution 1, small quantities of salts of about $10 \mathrm{~g}$ were weighed and dissolved in a $1000 \mathrm{~mL}$ beaker with tap water and stirred for at least $5 \mathrm{~min}$ on a magnetic stirrer. These concentrated solutions were then mixed together and diluted to $20 \mathrm{~L}$. Adjustments of $\mathrm{pH}$ of prepared solutions were done using sodium hydroxide $(\mathrm{NaOH})$ pellets. Approximately $5 \mathrm{~g}$ of $\mathrm{NaOH}$ pellets were used to obtain a $\mathrm{pH}$ range between 8 and 9. The second salt solution was prepared by dissolving approximately $105 \mathrm{~g}$ of each salt using a similar approach to Solution 1, also made up to $20 \mathrm{~L}$.

\section{Geyser heating element experiments}

\section{Water analysis}

The tap water sample from the $\mathrm{H} 2 \mathrm{O}$ Science Laboratory was sent to the Central Water Laboratory in the Eskom Research, Testing, and Development Business Unit for analysis to better understand the chemistry of the water used for geyser heating element experiments (Appendix A). In addition, the water samples of the two prepared salt solutions were tested at the same laboratory.

\section{Scaling acceleration of heating element experiments}

The electrical geyser heating elements were exposed to prepared salt solutions in $20 \mathrm{~L}$ buckets. The geyser heating element thermostats were set to $70^{\circ} \mathrm{C}$ instead of the normal geyser heating 
element temperature of $50^{\circ} \mathrm{C}$ or $65^{\circ} \mathrm{C}$. The increased temperature accelerated the scaling process, as the higher temperature caused calcium carbonate to precipitate out of the solution and produce scale in the water heaters (Widder and Baechler, 2013). The accelerated scaling experiments ran for at least 2 to 3 months. Scale deposit formation of the geyser heating elements being tested and inspected was photographed before testing and during the 2 to 3 months of the scaling period. Accelerated scaling method experiments, indicating the type of heating element and experimental conditions, are shown in Table 5.

\section{Power consumption experiments}

The energy consumption was measured for both new and trial geyser heating elements to monitor the power used during the experiments. Wireless electricity monitors were used in these experiments, mainly to monitor and display the power used by the geyser heating elements. In addition, these monitors were used to provide evidence of the overall time used for the scaling acceleration of each geyser heating element. Wireless electricity monitors were used as a troubleshooting mechanism to indicate whether the heating elements were, in fact, drawing power and were functional. These monitors showed the amount of power each geyser heating element consumed while running. Portable remote monitoring systems (PRMS) were also used to record the power consumption and temperature of the geyser heating elements while testing them. These PRMS were calibrated before being utilised. A PT100 resistance temperature detector ranging between $0^{\circ} \mathrm{C}$ and $100^{\circ} \mathrm{C}$ was installed in the data logger for temperature measurements of the geyser heater elements. The power consumption experiments, indicating the type of heating element and experimental conditions, are shown in Table 6.

\section{Heating cycle and temperature experiments of heating elements}

The aim of heating cycle and temperature experiments was to show whether scaling deposits could affect the heating process of heating elements. The heating cycle and temperature reading experiments are shown in Table 7. These experiments were done by setting a thermostat temperature at $50^{\circ} \mathrm{C}$ or $60^{\circ} \mathrm{C}$ with unscaled and scaled heating elements. The fluctuation behaviour of the heating cycle and temperature of the heating elements was observed.

\section{Electronic descaler technology experiments}

Electronic descaler technology is an inexpensive technology that can be applied externally to water system pipes for treatment of scale formation. The treatment is achieved by connecting the descaler technology to the water heater bucket with the heating element being tested. This technology does not require cutting or plumbing of pipework. The descaler technology produces a frequency-modulated waveform. On application of these frequencies, an oscillating electric field is generated in the water, which agitates the water molecules. This ultimately triggers carbon dioxide $\left(\mathrm{CO}_{2}\right)$ release, resulting in premature precipitation of calcium bicarbonate. Figure 2 shows the exterior and interior of the electronic descaler technology, as well the heating element experiment, with and without the descaler. The electronic descaler technology experiments, indicating the type of heating element and experimental conditions, are shown in Table 8.

\section{RESULTS AND DISCUSSION}

\section{Water analysis}

Table 9 provides the water chemistry results for tap water sampled from the $\mathrm{H} 2 \mathrm{O}$ Science Laboratory and for the prepared salt solutions. A pH between 8 and 9 was achieved for the prepared salt solution. The Langelier saturation index (LSI), Ryznar stability index (RSI), and Puckorius scaling index (PSI) were also calculated for the tap water and prepared Salt Solutions 1 and 2, presented in Table 9. Furthermore, tap water from the $\mathrm{H} 2 \mathrm{O}$ Science Laboratory was classified based on the concentration of total water hardness. The obtained calcium $(\mathrm{Ca})$ hardness as $\mathrm{CaCO}_{3}$ was $59.94 \mathrm{mg} / \mathrm{L}$, the magnesium $(\mathrm{Mg})$ hardness as $\mathrm{CaCO}_{3}$ was $24.69 \mathrm{mg} / \mathrm{L}$, and the total water hardness as $\mathrm{CaCO}_{3}$ was $84.63 \mathrm{mg} / \mathrm{L}$ for the tap water. Therefore, the tap water that was used to prepare salt solutions was classified as moderately hard water, which falls under the 61 to $120 \mathrm{mg} / \mathrm{L}$ as $\mathrm{CaCO}_{3}$ category, based on Table 2 .

\begin{tabular}{|c|c|c|c|c|c|c|}
\hline \multicolumn{7}{|c|}{$\begin{array}{c}\text { TABLE } 5 \\
\text { Scaling acceleration of heating element experiments }\end{array}$} \\
\hline Experiment No. & $\begin{array}{l}\text { Heating } \\
\text { element }\end{array}$ & $\begin{array}{l}\text { Heating element surface } \\
\text { coating }\end{array}$ & $\begin{array}{l}\text { Operating } \\
\text { temperature }\end{array}$ & Solution type & Scaling duration & Results \\
\hline A1 & $\begin{array}{l}1.5 \mathrm{~kW} \\
\text { Control }\end{array}$ & $\begin{array}{l}\text { New straight-shaped heating } \\
\text { element, copper-coated, with } \\
\text { nickel }\end{array}$ & $70^{\circ} \mathrm{C}$ & Tap water & 0 weeks & Fig. 3 \\
\hline A2 & $1.5 \mathrm{~kW}$ & $\begin{array}{l}\text { Straight-shaped heating } \\
\text { element, copper-coated, with } \\
\text { nickel }\end{array}$ & $70^{\circ} \mathrm{C}$ & Salt Solution 1 & 4 weeks & Fig. 3 \\
\hline A3 & $1.5 \mathrm{~kW}$ & $\begin{array}{l}\text { Straight-shaped heating } \\
\text { element, copper-coated, with } \\
\text { nickel }\end{array}$ & $70^{\circ} \mathrm{C}$ & Salt Solution 1 & 9 weeks & Fig. 3 \\
\hline B1 & $\begin{array}{c}3 \mathrm{~kW} \\
\text { Control }\end{array}$ & $\begin{array}{l}\text { New spiral-shaped copper- } \\
\text { coated heating element }\end{array}$ & $70^{\circ} \mathrm{C}$ & Tap water & 0 weeks & Fig. 4 \\
\hline B2 & $3 \mathrm{~kW}$ & $\begin{array}{l}\text { Spiral-shaped copper-coated } \\
\text { heating element }\end{array}$ & $70^{\circ} \mathrm{C}$ & Salt Solution 1 & 4 weeks & Fig. 4 \\
\hline B3 & $3 \mathrm{~kW}$ & $\begin{array}{l}\text { Spiral-shaped copper-coated } \\
\text { heating element }\end{array}$ & $70^{\circ} \mathrm{C}$ & Salt Solution 1 & 9 weeks & Fig. 4 \\
\hline
\end{tabular}




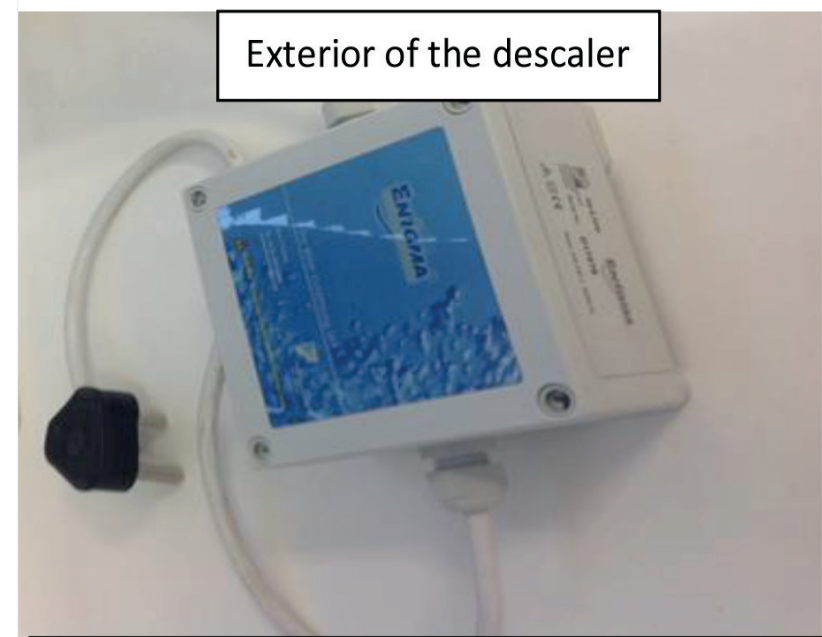

\section{Heating element experiment without descaler}

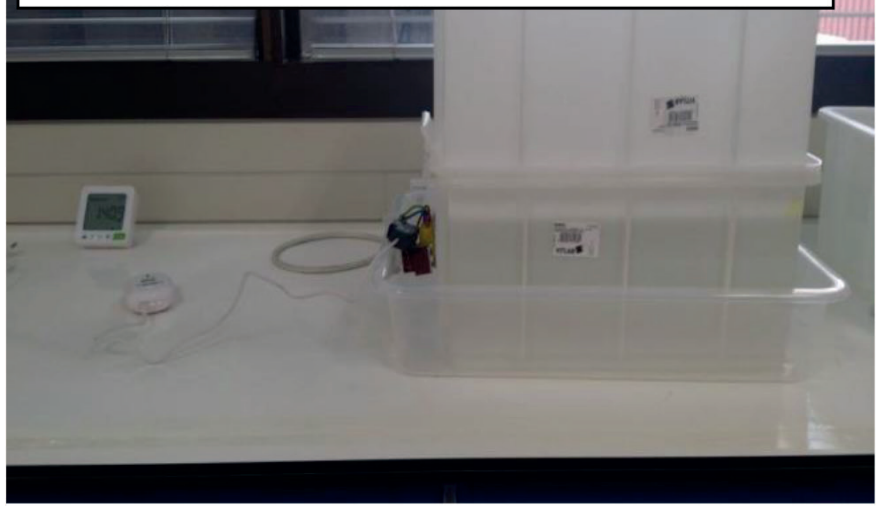

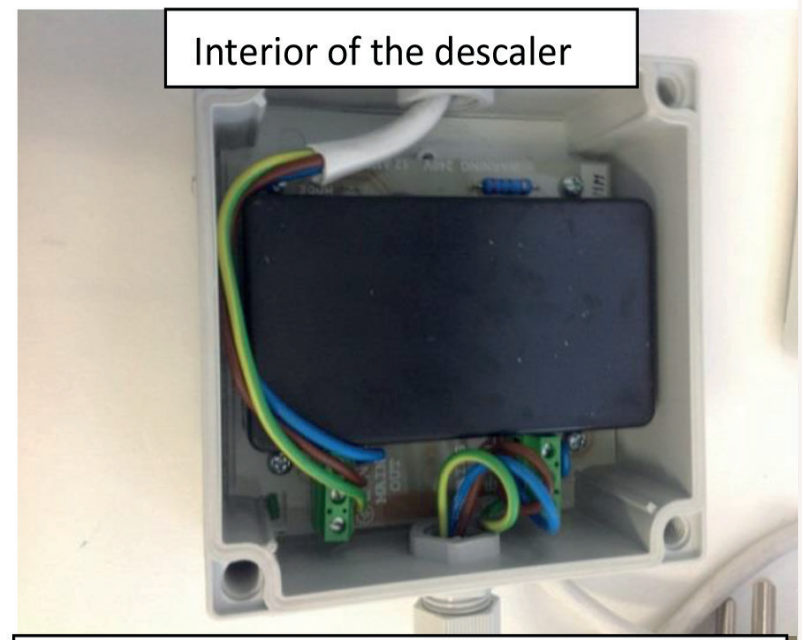

Heating element experiment with descaler

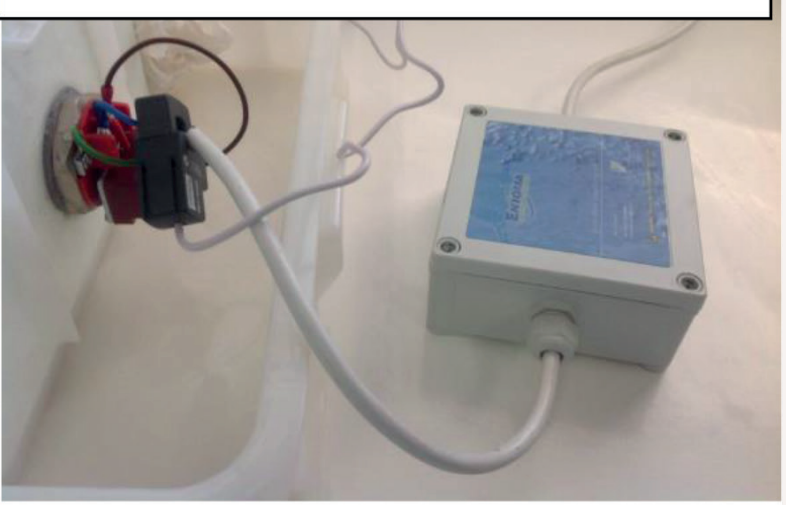

Figure 2

Electronic descaler technology

\begin{tabular}{|c|c|c|c|c|c|c|}
\hline \multicolumn{7}{|c|}{$\begin{array}{c}\text { TABLE } 6 \\
\text { Power consumption experiments }\end{array}$} \\
\hline $\begin{array}{l}\text { Experiment } \\
\text { No. }\end{array}$ & Heating element & Heating element description & $\begin{array}{l}\text { Operating } \\
\text { temperature }\end{array}$ & Solution type & Duration & Results \\
\hline A1 & $1.5 \mathrm{~kW}$ control & $\begin{array}{l}\text { New unscaled straight-shaped heating } \\
\text { element, copper-coated, with nickel }\end{array}$ & $50^{\circ} \mathrm{C}$ & Tap water & $7 \mathrm{~h}$ & Table 10 \\
\hline $\mathrm{A} 2$ & $1.5 \mathrm{~kW}$ & $\begin{array}{l}\text { Scaled straight-shaped heating element, } \\
\text { copper-coated, with nickel }\end{array}$ & $50^{\circ} \mathrm{C}$ & Salt Solution 1 & $7 \mathrm{~h}$ & Table 10 \\
\hline B1 & $3 \mathrm{~kW}$ control & $\begin{array}{l}\text { New unscaled spiral-shaped copper- } \\
\text { coated heating element }\end{array}$ & $50^{\circ} \mathrm{C}$ & Tap water & $7 \mathrm{~h}$ & Table 10 \\
\hline B2 & $3 \mathrm{~kW}$ & $\begin{array}{l}\text { Scaled spiral-shaped copper-coated } \\
\text { heating element }\end{array}$ & $50^{\circ} \mathrm{C}$ & Salt Solution 1 & $7 \mathrm{~h}$ & Table 10 \\
\hline $\mathrm{C} 1$ & $3 \mathrm{~kW}$ & $\begin{array}{l}\text { Scaled heating element, copper-coated, } \\
\text { with nickel, topped with Salt Solution 1, } \\
\text { with electronic descaler in-line }\end{array}$ & $50^{\circ} \mathrm{C}$ & Salt Solution 1 & $7 \mathrm{~h}$ & Table 10 \\
\hline $\mathrm{C} 2$ & $3 \mathrm{~kW}$ & $\begin{array}{l}\text { Scaled heating element, copper-coated, } \\
\text { with nickel, topped with tap water, with } \\
\text { electronic descaler in-line }\end{array}$ & $50^{\circ} \mathrm{C}$ & Tap water & $7 \mathrm{~h}$ & Table 10 \\
\hline $\mathrm{D} 2$ & $2 \mathrm{~kW}$ & $\begin{array}{l}\text { New straight-shaped heating element, } \\
\text { copper-coated, with nickel, with } \\
\text { electronic descaler in-line }\end{array}$ & $50^{\circ} \mathrm{C}$ & Salt Solution 1 & $7 \mathrm{~h}$ & Table 11 \\
\hline D3 & $2 \mathrm{~kW}$ control & $\begin{array}{l}\text { New straight-shaped heating element, } \\
\text { copper-coated, with nickel, without } \\
\text { descaler }\end{array}$ & $50^{\circ} \mathrm{C}$ & Tap water & $7 \mathrm{~h}$ & Table 11 \\
\hline
\end{tabular}




\begin{tabular}{|l|l|l|l|l|l|l|l|}
\hline \multicolumn{7}{|c|}{ Heating cycle and temperature reading experiments } \\
\hline $\begin{array}{l}\text { Experiment } \\
\text { No. }\end{array}$ & Heating element & \multicolumn{1}{|c|}{ Heating element description } & Room temp. & $\begin{array}{c}\text { Operating } \\
\text { temp. }\end{array}$ & Solution type & Duration & Results \\
\hline A1 & $1.5 \mathrm{~kW}$ control & $\begin{array}{c}\text { New unscaled straight-shaped heating } \\
\text { element, copper-coated, with nickel }\end{array}$ & 19 to $21^{\circ} \mathrm{C}$ & $60^{\circ} \mathrm{C}$ & Tap water & $7 \mathrm{~h}$ & Fig. 8 \\
\hline A2 & $1.5 \mathrm{~kW}$ & $\begin{array}{l}\text { Scaled straight-shaped heating element, } \\
\text { copper-coated, with nickel }\end{array}$ & 19 to $21^{\circ} \mathrm{C}$ & $50^{\circ} \mathrm{C}$ & Salt Solution 1 & $7 \mathrm{~h}$ & Fig. 11 \\
\hline A4 & $1.5 \mathrm{~kW}$ & $\begin{array}{c}\text { Scaled straight-shaped heating element, } \\
\text { copper-coated, with nickel }\end{array}$ & 19 to $21^{\circ} \mathrm{C}$ & $60^{\circ} \mathrm{C}$ & Salt Solution 2 & $7 \mathrm{~h}$ & Fig. 9 \\
\hline A5 & $1.5 \mathrm{~kW}$ contro & $\begin{array}{l}\text { New unscaled straight-shaped heating } \\
\text { element, copper-coated, with nickel }\end{array}$ & 19 to $21^{\circ} \mathrm{C}$ & $50^{\circ} \mathrm{C}$ & Tap water & $7 \mathrm{~h}$ & Fig. 10 \\
\hline B1 & $3 \mathrm{~kW}$ control & $\begin{array}{c}\text { New unscaled spiral-shaped copper- } \\
\text { coated heating element }\end{array}$ & 19 to $21^{\circ} \mathrm{C}$ & $50^{\circ} \mathrm{C}$ & Tap water & $7 \mathrm{~h}$ & Fig. 7 \\
\hline B2 & $3 \mathrm{~kW}$ & $\begin{array}{l}\text { Scaled spiral-shaped copper-coated } \\
\text { heating element }\end{array}$ & 19 to $21^{\circ} \mathrm{C}$ & $50^{\circ} \mathrm{C}$ & Salt Solution 1 & $7 \mathrm{~h}$ & Fig. 7 \\
\hline
\end{tabular}

\begin{tabular}{|l|l|l|c|c|c|c|}
\hline \multicolumn{7}{|c|}{ TABLE 8 } \\
\hline $\begin{array}{l}\text { Experiment } \\
\text { No. }\end{array}$ & Heating element & \multicolumn{1}{|c|}{ Heating element description } & $\begin{array}{c}\text { Operating } \\
\text { temperature }\end{array}$ & Solution type & Duration & Results \\
\hline D1 & $2 \mathrm{~kW}$ control & $\begin{array}{l}\text { New straight-shaped heating element, } \\
\text { copper-coated, with nickel, without } \\
\text { descaler }\end{array}$ & $70^{\circ} \mathrm{C}$ & Salt Solution 1 & 13 weeks & Fig. 12 \\
\hline D2 & $2 \mathrm{~kW}$ & $\begin{array}{l}\text { New straight-shaped heating element, } \\
\text { copper-coated, with nickel, with } \\
\text { electronic descaler in-line }\end{array}$ & $70^{\circ} \mathrm{C}$ & Salt Solution 1 & 13 weeks & Fig. 12 \\
\hline
\end{tabular}

\begin{tabular}{|c|c|c|c|c|}
\hline \multicolumn{5}{|c|}{$\begin{array}{c}\text { TABLE } 9 \\
\text { Water chemistry of tap water and prepared salt solutions }\end{array}$} \\
\hline Chemical parameters & SI unit & Tap water & Salt Solution 1 & Salt Solution 2 \\
\hline $\mathrm{pH}$ at $25^{\circ} \mathrm{C}$ & & 7.48 & 8.12 & 8.96 \\
\hline TDS & $\mathrm{mg} / \mathrm{L}$ & 154.4 & 5202.2 & 8649.6 \\
\hline Calcium hardness & $\mathrm{mg} / \mathrm{L} \mathrm{CaCO}_{3}$ & 59.94 & 2247.75 & 9990.01 \\
\hline Alkalinity & $\mathrm{mg} / \mathrm{L} \mathrm{CaCO}_{3}$ & 77.83 & 3363 & 6593 \\
\hline Water temperature & ${ }^{\circ} \mathrm{C}$ & 25 & 25 & 25 \\
\hline \multirow{3}{*}{$\begin{array}{l}\text { Langelier saturation } \\
\text { index (LSI) results }\end{array}$} & $\mathrm{pHs}$ & 8.24 & 5.18 & 4.26 \\
\hline & $\mathrm{pH}-\mathrm{pHs}$ & -0.76 & 2.94 & 4.70 \\
\hline & LSI indication & $\begin{array}{l}\text { Water is undersaturated; } \\
\text { tends to dissolve calcium } \\
\text { carbonate }\left(\mathrm{CaCO}_{3}\right)\end{array}$ & $\begin{array}{l}\text { Water is supersaturated; } \\
\text { tends to precipitate } \mathrm{CaCO}_{3}\end{array}$ & $\begin{array}{l}\text { Water is supersaturated; } \\
\text { tends to precipitate } \mathrm{CaCO}_{3}\end{array}$ \\
\hline \multirow{2}{*}{$\begin{array}{l}\text { Ryznar stability index } \\
\text { (RSI) results }\end{array}$} & $2 \mathrm{pHs}-\mathrm{pH}$ & 9.0 & 2.24 & -0.44 \\
\hline & RSI indication & Corrosion tendency & Scaling tendency & $\begin{array}{l}\text { Undersaturated; tends to } \\
\text { dissolve solid } \mathrm{CaCO}_{3}\end{array}$ \\
\hline \multirow{3}{*}{$\begin{array}{l}\text { Puckorius scaling } \\
\text { index (PSI) results }\end{array}$} & $\mathrm{pH}_{\mathrm{eq}}$ & 7.31 & 9.71 & 10.14 \\
\hline & $2 \mathrm{pHs}-\mathrm{pH}_{\mathrm{eq}}$ & 9.17 & 0.65 & -1.62 \\
\hline & PSI indication & Likely to dissolve scale & Heavy scale & Heavy scale will form \\
\hline
\end{tabular}


In addition, the scaling and corrosion indices for tap water were calculated to indicate whether the tap water influenced the scaling formation or corrosive region of the geyser heating elements, as shown in Table 9. The tap water LSI of -0.76 indicated that the water was undersaturated, with a tendency to remove existing calcium carbonate scaling. The tap water RSI of 9.0 and PSI of 9.17 concurred that the tap water was more likely to cause corrosion than scaling. Therefore, it was clear that the chemistry of the tap water at the $\mathrm{H} 2 \mathrm{O}$ Science Laboratory needed to be changed so that more scaling would be formed.

Salt Solution 1 contained calcium (Ca) hardness as $\mathrm{CaCO}_{3}$ of $2247.75 \mathrm{mg} / \mathrm{L}$, magnesium $(\mathrm{Mg})$ hardness as $\mathrm{CaCO}_{3}$ of $2633.74 \mathrm{mg} / \mathrm{L}$, and total water hardness as $\mathrm{CaCO}_{3}$ of $4881.49 \mathrm{mg} / \mathrm{L}$. The total dissolved solids (TDS) in prepared Salt Solution 1 measured $5202.2 \mathrm{mg} / \mathrm{L}$. Therefore, prepared Salt Solution 1 was classified as moderately saline water, categorised between 1500 and $7000 \mathrm{mg} / \mathrm{L}$ of TDS, based on Table 4. For prepared Salt Solution 1, the LSI was 2.94, RSI was 2.24, and PSI was 0.64 , indicating that the water was supersaturated and had a tendency to form heavy and serious scaling. The results for prepared Salt Solution 2 showed Ca hardness as $\mathrm{CaCO}_{3}$ of $9990.01 \mathrm{mg} / \mathrm{L}, \mathrm{Mg}$ hardness as $\mathrm{CaCO}_{3}$ of $4938.27 \mathrm{mg} / \mathrm{L}$, and total water hardness as $\mathrm{CaCO}_{3}$ of $14928.28 \mathrm{mg} / \mathrm{L}$. The TDS in prepared Salt Solution 2 was $8649.60 \mathrm{mg} / \mathrm{L}$. This meant that the prepared Salt Solution 2 was classified as highly saline and categorised between 7000 and $15000 \mathrm{mg} / \mathrm{L}$ of TDS, based on Table 4. For Salt Solution 2, the LSI was 4.70, RSI was -0.44 , and PSI was -1.62 , indicating that the water was supersaturated and had a tendency to form heavy and serious scaling, as shown in Table 9.

\section{Scaling acceleration of heating elements}

The first objective of this research was to develop a scaling acceleration method to shorten the test times for scaling the geyser heating elements (refer to Table 5 for experimental set up). In Experiment A1, prepared Salt Solution 1 was applied to a $1.5 \mathrm{~kW}$ straight-shaped copper geyser heating element, coated with nickel. Figure 3 shows experimental results of the $1.5 \mathrm{~kW}$ straight shaped heating element. In A1 (control), no scaling was formed. In A2, the build-up of scaling had started, which is called the nucleation stage, after 4 weeks of the trial. In A3, about a 1 to $3 \mathrm{~mm}$ layer of lime scale was formed.

Figure 4 illustrates the state before and after a spiralshaped copper $3 \mathrm{~kW}$ geyser heating element was exposed to the accelerated scaling process. Experiment B1 in Fig. 4 shows a new unscaled copper-coated $3 \mathrm{~kW}$ geyser heating element control. Experiment B2 shows the nucleation stage after 4 weeks of running the trial. Lastly, Experiment B3 shows a scaled $3 \mathrm{~kW}$ geyser heating element after 9 weeks of trial. The scale formation of the copper-coated surface $3 \mathrm{~kW}$ geyser heating element in Fig. 4 was not as significant as the coppercoated, with nickel, material of the heating element shown in Fig. 3. The copper material of the geyser heating element in Fig. 4 showed more resistance to scale formation than the copper-coated, with nickel, material. The findings of both experiments A and B confirmed that the developed scaling acceleration was a success, and the geyser heating elements were able to form scale within 9 weeks of the trials.
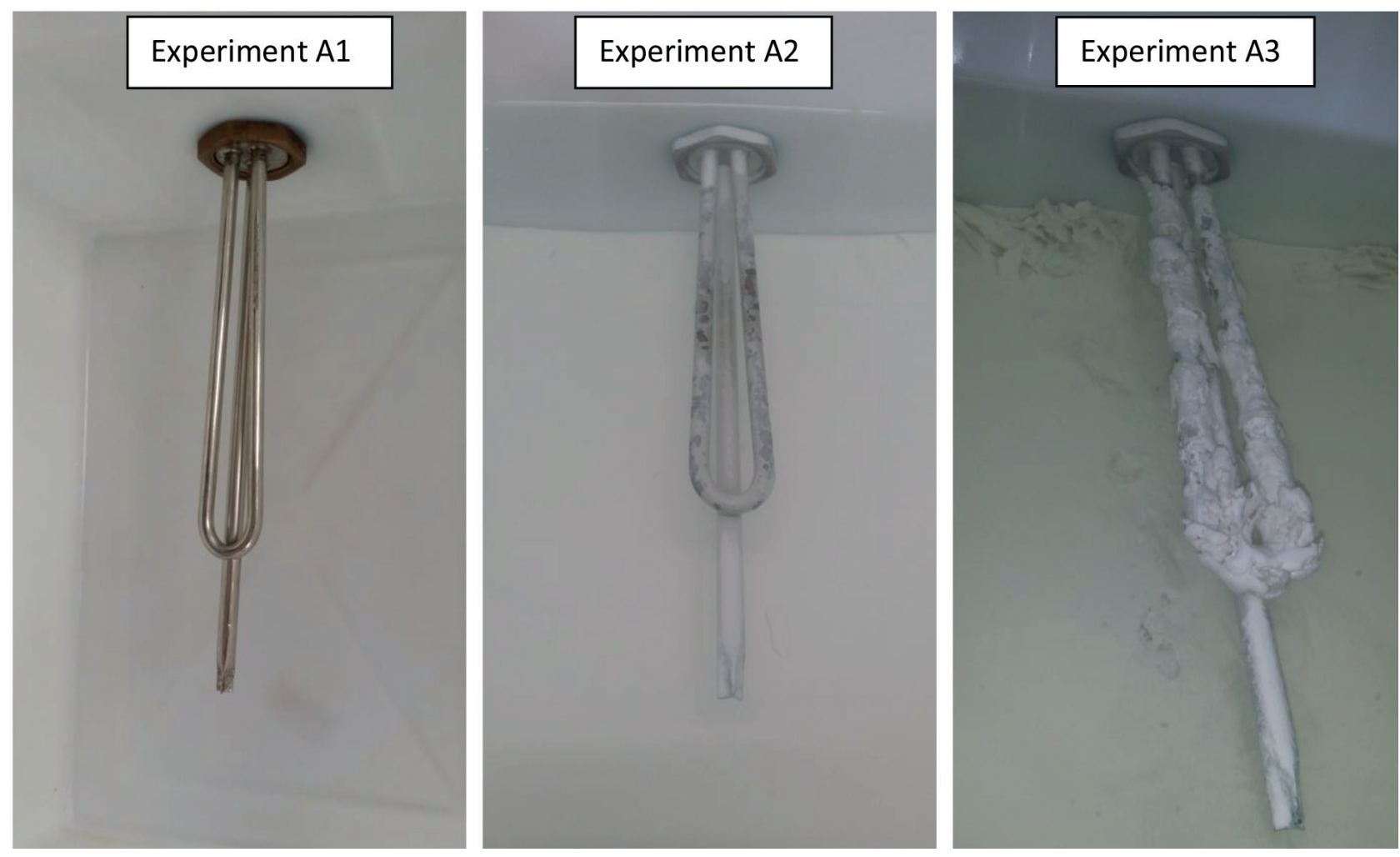

Figure 3

Scaling of $1.5 \mathrm{~kW}$ heating element, copper-coated, with nickel 

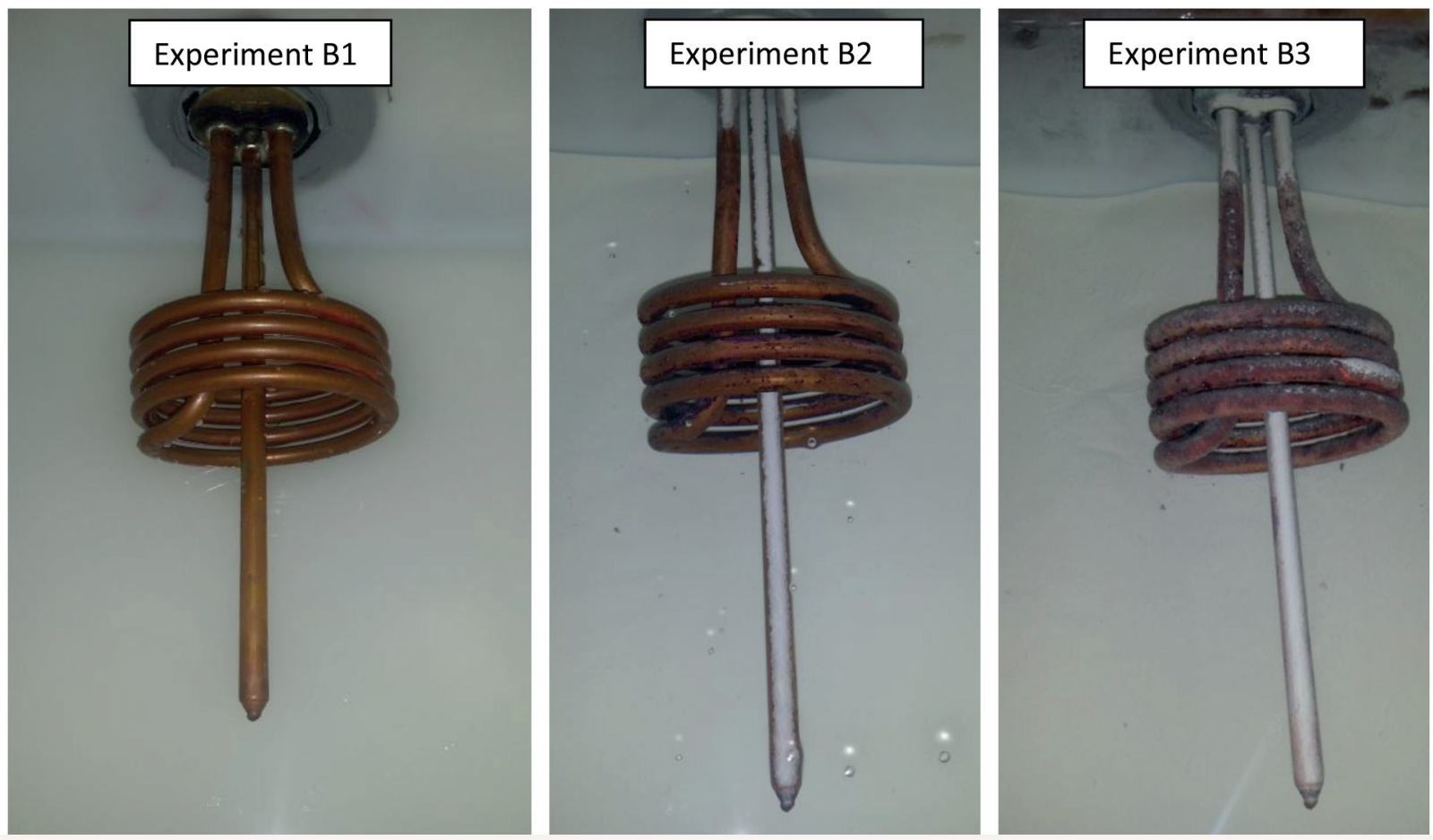

Figure 4

Scaling of $3 \mathrm{~kW}$ copper-coated heating element

\section{Power consumption of heating elements}

The second research objective was to investigate the relationship between the power consumption of geyser heating elements and scaling formation due to total water hardness. The power consumption of scaled geyser heating elements was compared to new unscaled geyser heating elements. The power consumption experimental conditions indicating the type of heating element are shown in Table 6 . The first trial was to compare the power consumption of the scaled copper-coated, with nickel, $1.5 \mathrm{~kW}$ geyser heating element (A2) to the unscaled new heating element control (A1). Table 10 shows the power consumption comparison results of the scaled A2 experiment and the unscaled A1 experiment. The overall findings showed that the build-up of calcium carbonate deposits on the geyser heating elements led to increased power consumption by $6.8 \%$.

The second trial was to compare a scaled copper-coated $3 \mathrm{~kW}$ geyser heating element (B2) to the unscaled new heating element control (B1). The overall findings showed that the difference in power consumption between Experiments B1 and $\mathrm{B} 2$ was $11.8 \%$ (Table 10 ). The above experiments have indicated that scale formation on heating elements resulting from water hardness had an impact on power consumption. The third trial involved two scaled $3 \mathrm{~kW}$ copper-coated, with nickel, heating elements, connected to the descaler; the only difference was that one heating element was immersed in the prepared Salt Solution 1 (C1), and another heating element immersed in tap water (C2). Figure 5 shows images of Experiments $\mathrm{C} 1$ and $\mathrm{C} 2$. About a $3.7 \%$ difference in power consumption between Experiments $\mathrm{C} 1$ and $\mathrm{C} 2$ was obtained (Table 10). The findings of this trial also confirmed that a change in solution media from prepared salt solution to tap water lowered the power consumption percentage.

Figure 6 shows the typical heating cycle and power consumption of a $3 \mathrm{~kW}$ heating element for a testing period of 7 $\mathrm{h}$ (B2). The heating element was set at $50^{\circ} \mathrm{C}$ on a thermostat,

\begin{tabular}{|c|c|c|c|}
\hline \multicolumn{4}{|c|}{$\begin{array}{c}\text { TABLE } 10 \\
\text { Power consumption comparison of heating elements }\end{array}$} \\
\hline Heating element & $\begin{array}{l}\text { Heating } \\
\text { element }(\mathrm{kW})\end{array}$ & Difference $(\mathrm{kW})$ & Difference (\%) \\
\hline $\begin{array}{l}\text { Experiment A1 - new unscaled straight-shaped } 1.5 \mathrm{~kW} \text { heating element, copper- } \\
\text { coated, with nickel }\end{array}$ & 82.65 & \multirow[t]{2}{*}{6.01} & \multirow[t]{2}{*}{6.8} \\
\hline Experiment A2 - scaled copper-coated, with nickel, $1.5 \mathrm{~kW}$ heating element & 88.66 & & \\
\hline Experiment B1 - new unscaled spiral-shaped copper-coated $3 \mathrm{~kW}$ heating element & 91.92 & \multirow{2}{*}{12.25} & \multirow{2}{*}{11.8} \\
\hline Experiment B2 - scaled spiral-shaped copper-coated $3 \mathrm{~kW}$ heating element & 104.17 & & \\
\hline $\begin{array}{l}\text { Experiment } \mathrm{C} 1 \text { - scaled copper-coated, with nickel, } 3 \mathrm{~kW} \text { heating element, topped } \\
\text { with salt solution, with electronic descaler in-line }\end{array}$ & 95.46 & \multirow{2}{*}{3.54} & \multirow{2}{*}{3.7} \\
\hline $\begin{array}{l}\text { Experiment C } 2 \text { - previously scaled copper-coated, with nickel, } 3 \mathrm{~kW} \text { heating ele- } \\
\text { ment, topped with tap water, with electronic descaler in-line }\end{array}$ & 91.92 & & \\
\hline
\end{tabular}



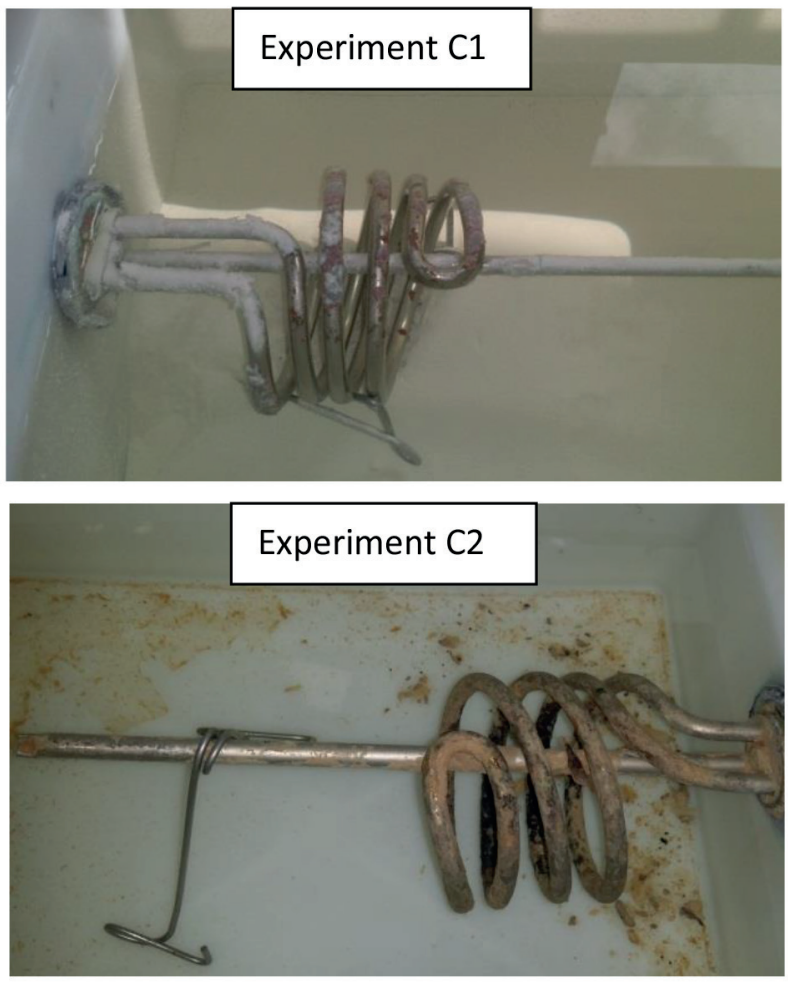

Figure 5

Scaled $3 \mathrm{~kW}$ heating element with descaler technology in tap water

and then the power consumption was observed as the thermostat switched on and off. The results of these power consumption trials proved that scale formation of $1.5 \mathrm{~kW}$ and $3 \mathrm{~kW}$ geyser heating elements due to high total water hardness increased the power consumption by approximately $4 \%$ to $12 \%$.

\section{Heating cycle and temperature event fluctuations of heating elements}

The heating cycle and temperature event fluctuation behaviour of heating elements was investigated by observing the behaviour of scaled and unscaled heating elements when a thermostat was set at a certain temperature. The experiments, indicating the type of heating element and experimental conditions for heating cycle and temperature event fluctuations, are shown in Table 7. An unscaled spiral-shaped $3 \mathrm{~kW}$ scaled coppercoated heating element (B1), was compared to a scaled one (B2). Figure 7 shows the results of the temperature readings for Experiments $\mathrm{B} 1$ and $\mathrm{B} 2$ at $50^{\circ} \mathrm{C}$ on the thermostat. These results indicate that the temperature of the scaled element (B2) was, on average, higher than that of the unscaled B1. It can also be predicted that, based on the results shown in Fig. 7, the scale formation in Experiment B2 caused the rise in temperature above the set point of $50^{\circ} \mathrm{C}$, eventually increasing the power consumption.

A second trial was performed to compare the heating cycle of an unscaled straight-shaped $1.5 \mathrm{~kW}$ copper-coated heating element (A1) with the scaled heating element (A4). Figures 8 and 9 show the typical temperature and heating cycle of Experiments A1 and A4, respectively. The results presented in Fig. 8 illustrate the typical or normal behaviour of a new heating element with a thermostat switching on and off within $5^{\circ} \mathrm{C}$ to $6^{\circ} \mathrm{C}$ of the set $60^{\circ} \mathrm{C}$ thermostat temperature. The fluctuations

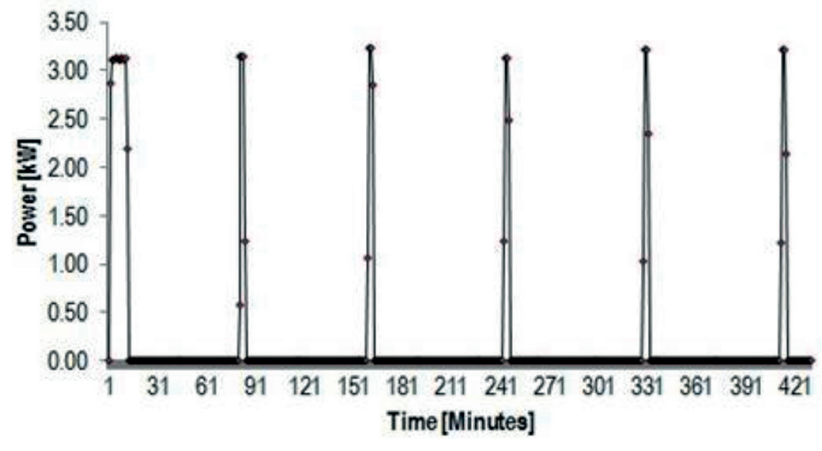

Figure 6

Power consumption of $3 \mathrm{~kW}$ heating element

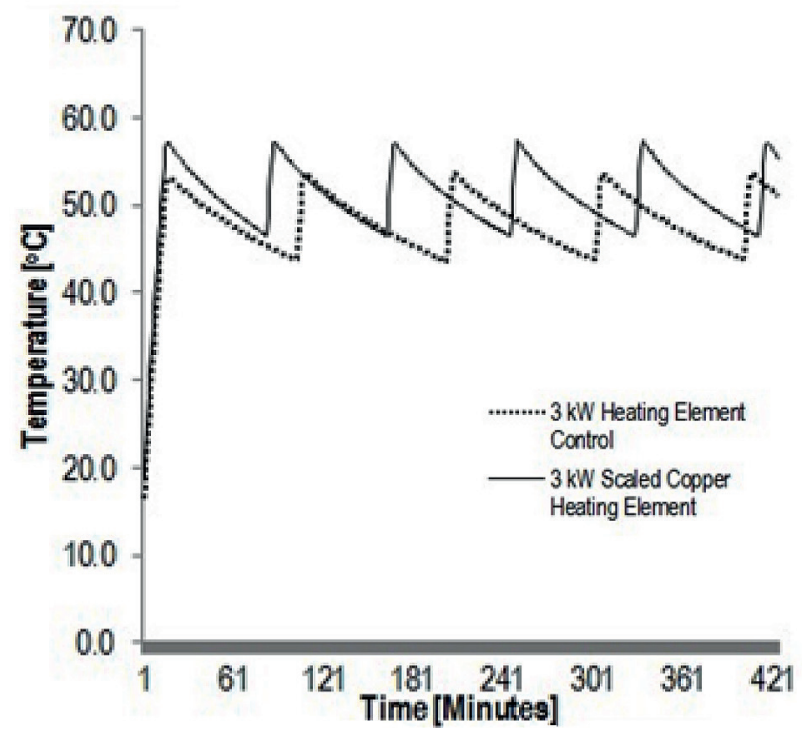

Figure 7

Heating cycle of $3 \mathrm{~kW}$ heating element with control

in the temperature findings shown in Fig. 9 for Experiment A4 did not define the start and stop events, which ought to depend on the set temperature of the thermostat of $60^{\circ} \mathrm{C}$, compared to the $\mathrm{A} 1$ results depicted in Fig. 8. These findings showed that the thermostat temperature was about $40^{\circ} \mathrm{C}$ instead $60^{\circ} \mathrm{C}$. The results in Fig. 9 confirmed that the scale formation due to scale deposits on the heating elements led to decreased operational performance of the thermostat. Scaling of heating elements due to total water hardness caused drifting of the thermostat temperature setting.

The last experiment (A2) was performed with a scaled $1.5 \mathrm{~kW}$ straight-shaped copper-coated heating element, which was immersed in prepared Salt Solution 1 at $50^{\circ} \mathrm{C}$. Figure 11 shows the results obtained in Experiment A2. The findings for A2 indicated a different abnormal fluctuation behaviour of temperature compared with unscaled $1.5 \mathrm{~kW}$ heating element (A5), as shown in Fig. 10. The start and stop temperature events in Fig. 11 were abnormal and longer. Typically, a thermostat will switch on and off every $30 \mathrm{~min}$, as shown in Fig. 10, but in Fig. 11 it is seen that this occurred after about $1.5 \mathrm{~h}$. These results confirmed the inefficient performance of the thermostat caused by scale formation on heating elements. 


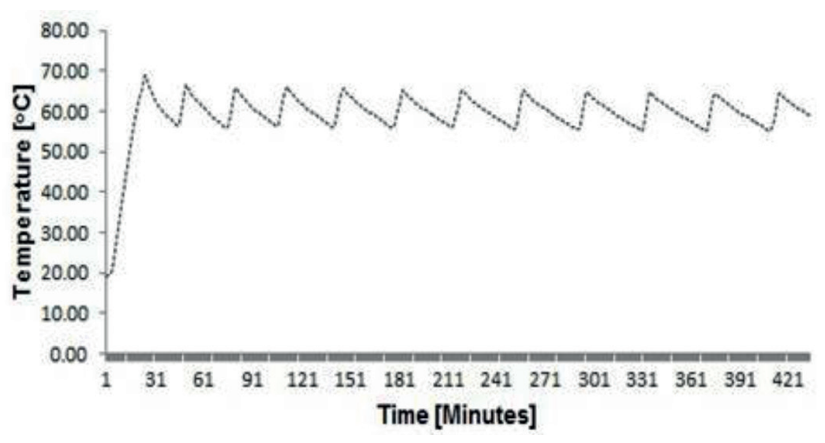

Figure 8

Heating cycle of $1.5 \mathrm{~kW}$ heating element control in tap water

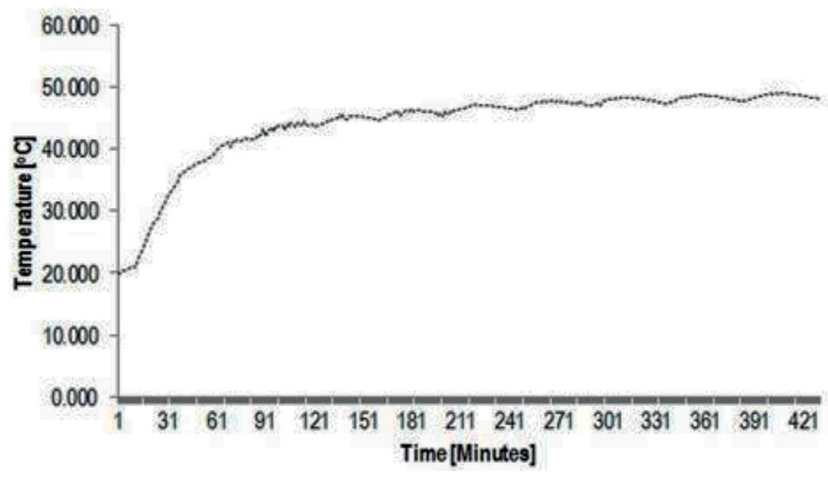

Figure 9

Heating cycle of scaled $1.5 \mathrm{~kW}$ heating element in Salt Solution 2

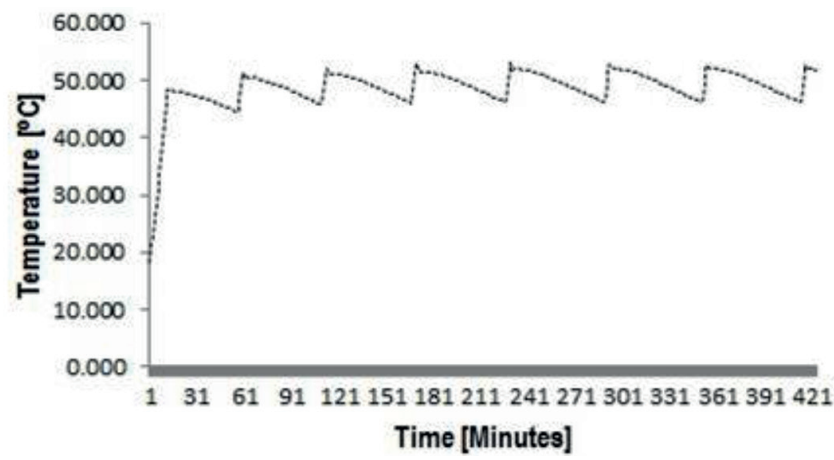

Figure 10

Heating cycle of $1.5 \mathrm{~kW}$ heating element control in tap water

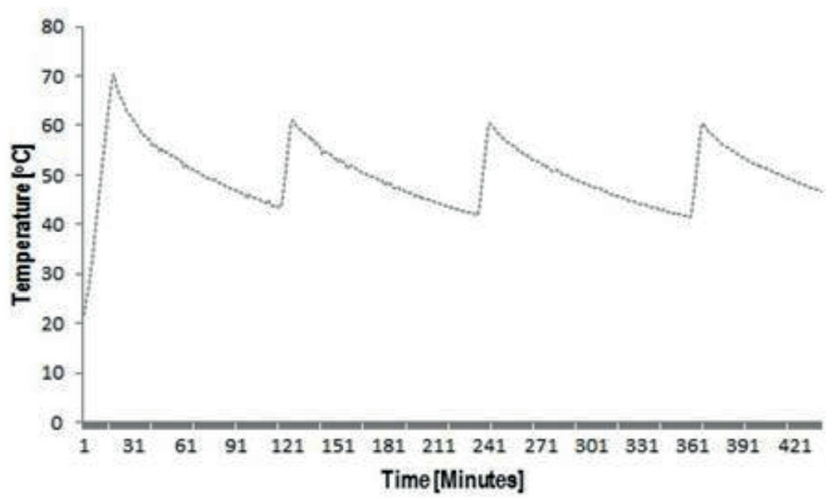

Figure 11

Heating cycle of scaled $1.5 \mathrm{~kW}$ heating element in Salt Solution 1

\section{Electronic descaler technology}

The third research objective was to investigate whether the descaler technology would inhibit or minimise the scaling formation on the $2 \mathrm{~kW}$ geyser heating element. Experiment D1, a new $2 \mathrm{~kW}$ straight-shaped heating element, copper-coated, without descaler was compared to Experiment D2 connected to a descaler. The type of heating element and experimental conditions are shown in Table 8. Figure 12 shows that there was insignificant scale formation in Experiment D2 because the descaler technology was connected, compared to the heating element without the descaler in D1. These results confirmed that electronic descaler technology did, indeed, minimise the formation of scaling deposits on the $2 \mathrm{~kW}$ geyser heating element.

Another trial was performed to investigate the amount of power used by the electronic descaler to provide evidence that the descaler did not have excessive power consumption. A new straight-shaped $2 \mathrm{~kW}$ heating element, copper-coated, with descaler (D2) was compared to Experiment D3 without descaler (refer to Table 6 for experimental set up). Table 11 shows the obtained power consumption difference between Experiments $\mathrm{D} 3$ and $\mathrm{D} 2$ to be $0.47 \mathrm{~kW}$. These results confirmed that lower power usage was required by the descaler to minimise scale formation on the heating elements. In addition, the overall power consumption findings of Experiment D2 with a descaler are illustrated in Figs 13 and 14.

Figure 13 shows the 1-h heating cycle results of Experiment D2 with the thermostat set at $50^{\circ} \mathrm{C}$. In Fig. 13, it can be observed that about $2.2 \mathrm{~kW}$ of power was consumed with the $2 \mathrm{~kW}$ heating element in a salt solution connected to the descaler. These results showed that the heating element continued to consume the same amount of power for about $25 \mathrm{~min}$, and only after $30 \mathrm{~min}$ did the heating element switch on to
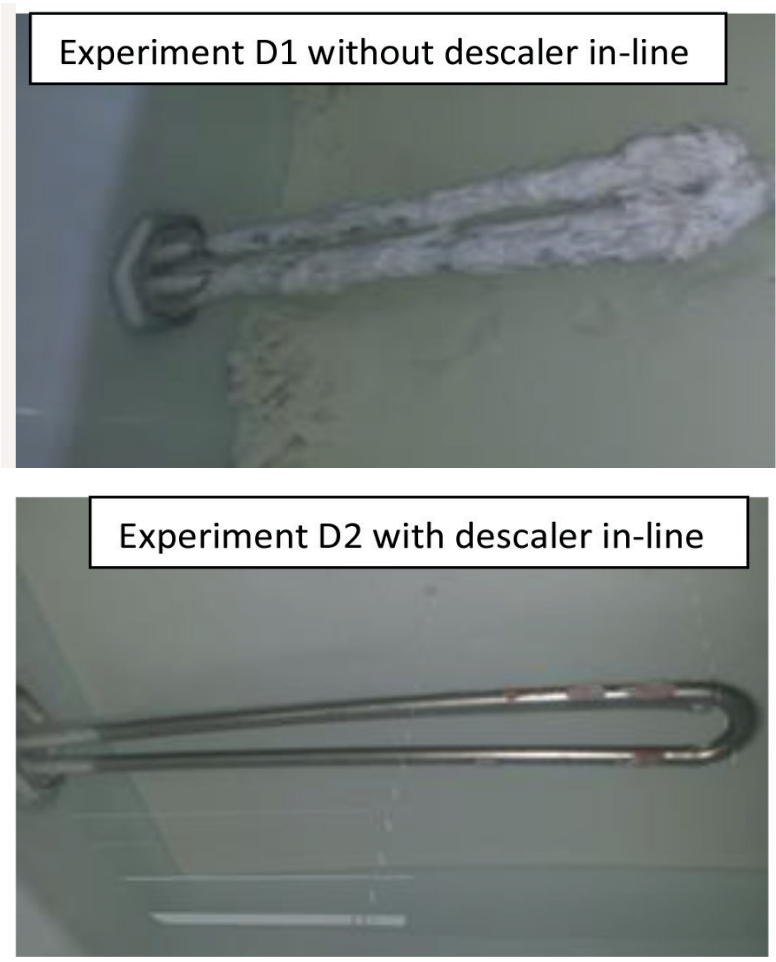

Figure 12

A 2 kW heating element with descaler technology in Salt Solution 1 


\begin{tabular}{|l|c|c|c|}
\hline \multicolumn{4}{|c|}{ TABLE 11 } \\
Power consumption of the electronic descaler \\
\hline Heating element & $\begin{array}{c}\text { Heating } \\
\text { element (kW) }\end{array}$ & $\begin{array}{c}\text { Difference } \\
\text { (kW) }\end{array}$ & $\begin{array}{c}\text { Difference } \\
\text { (\%) }\end{array}$ \\
\hline $\begin{array}{l}\text { Experiment D2 - new } \\
\text { straight-shaped 2 kW } \\
\text { heating element, copper- } \\
\text { coated, with nickel, with } \\
\text { descaler in-line }\end{array}$ & 86.56 & & \\
\hline $\begin{array}{l}\text { Experiment D3 - new } \\
\text { straight-shaped 2 kW } \\
\text { heating element, copper- } \\
\text { coated, with nickel, } \\
\text { without descaler }\end{array}$ & 86.09 & 0.47 & 0.54 \\
\hline
\end{tabular}

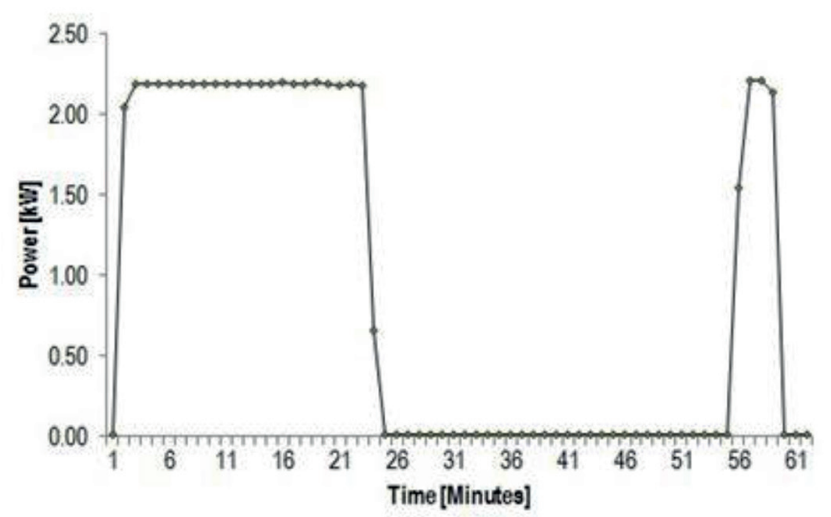

Figure 13

1-hour heating cycle of $2 \mathrm{~kW}$ heating element with descaler

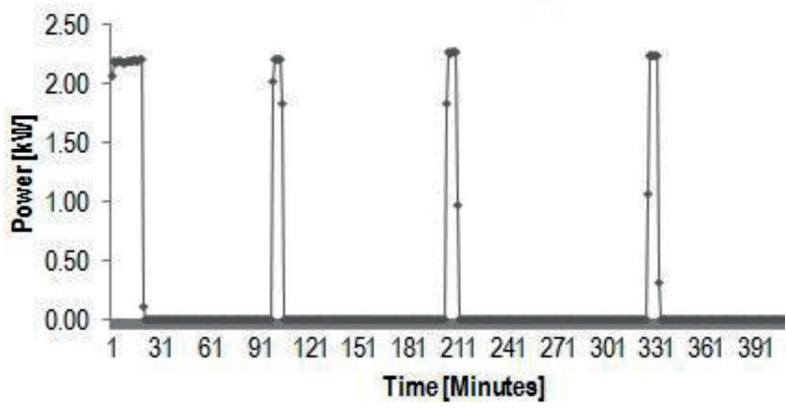

Figure 14

Power consumption of $2 \mathrm{~kW}$ heating element with descaler technology in-line

consume more power. Figure 13 shows that the amount of power required for the descaler to treat scale build-up was low; hence, it was regarded as energy efficient. Figure 14 shows the additional results of Experiment D2; the duration of the experiment was, however, $7 \mathrm{~h}$. The findings in Fig. 14 indicated that about $2.2 \mathrm{~kW}$ of peak power was consumed throughout the testing period. The heating cycle pattern was delayed to about $60 \mathrm{~min}$, as shown in Fig. 14. This might be due to the fact that Salt Solution 1, with high water hardness, was used in this experiment. The third objective was, thus, achieved because the descaler was able to minimise scale formation at a lower power usage.

\section{CONCLUSION}

This research sought to investigate the impact of scale formation due to total water hardness on the power consumption of hot water technologies such as geyser heating elements. The first research objective was to develop a scaling acceleration method to shorten the time required for geyser heating element testing. The acceleration method was developed using calcium carbonate $\left(\mathrm{CaCO}_{3}\right)$, calcium sulphate $\left(\mathrm{CaSO}_{4} \cdot 2 \mathrm{H}_{2} \mathrm{O}\right)$, magnesium chloride hexahydrate $\left(\mathrm{MgCl}_{2} \cdot 6 \mathrm{H}_{2} \mathrm{O}\right)$, and magnesium sulphate $\left(\mathrm{MgSO}_{4} \cdot 7 \mathrm{H}_{2} \mathrm{O}\right)$. Scaling formation acceleration factors included a fixed operating thermostat temperature of $70^{\circ} \mathrm{C}$, a scale formation time of 2 to 3 months, Salt Solution 1, and a pH range between 8 and 9 . The development of a scaling acceleration method for heating elements was achieved.

The second research objective investigated the relationship between power consumption of geyser heating elements and scale formation due to total water hardness. It was shown that scale formation of heating elements increased power consumption by approximately $4 \%$ to $12 \%$, depending on the type of material of the heating element and scale formation layer. Moreover, it was found that scaling altered the set temperature of thermostats, ultimately having an impact on the overall performance of heating elements.

The third research objective was to test electronic descaler technology on heating elements, using the accelerated scaling method. The overall findings indicated that there was minimal scale formation on the heating elements. The technology also operated successfully when a more concentrated solution (Salt Solution 1), was applied. In addition, the electronic descaler technology used an insignificant amount of power throughout the experimental duration when compared to the heating elements without the technology.

\section{ACKNOWLEDGEMENTS}

The author, Lerato Lethea, would like to extend her gratitude to the Demand Management Centre of Expertise Middle Manager, Mrs Ronel Clarke, at Eskom Research, Testing, and Development, for supporting this research project performed under the $\mathrm{H} 2 \mathrm{O}$ Science Laboratory. Her management and leadership are sincerely acknowledged.

\section{REFERENCES}

ANTONY A, LOW JH, GRAY S, CHILDRESS AE, LE-CLECH P and LESLIE g (2011) Scale formation and control in high pressure membrane water treatment systems: A review. J. Membr. Sci. 383 1-16. https://doi.org/10.1016/j.memsci.2011.08.054

ARUNCHALA UC (2011) Performance deterioration of thermosiphon solar flat plate water heater due to scaling. IIUM Eng. J. Special Issue, Mechanical Engineering, 2011 117-132.

BRAZEAU RH and EDWARDS MA (2011) A review of sustainability of residential hot water infrastructure: Public health, environmental impacts, and consumer drivers. J. Green Build. 6 (4) 77-95. https://doi.org/10.3992/jgb.6.4.77

CATHERINE Q, WHEELER J, WILKINSON R and DE JAGER g (2012) Hot water usage profiling to improve geyser efficiency. J. Energ. South. Afr. 23 (1) 39-45.

DE ZUANE J (1997) Handbook of Drinking Water Quality (2 ${ }^{\text {nd }}$ edn). John Wiley \& Sons Inc., New York. 29 pp.

DOBERSEK D and GORICANEC D (2007) Influence of water scale on thermal flow losses of domestic appliances. Int. J. Math. Models Meth. Appl. Sci. 2 (1) 55-61. https://doi.org/10.1016/j. energy.2014.09.024 
DOBERSEK D and GORICANEC D (2014) An experimentally evaluated magnetic device's efficiency for water-scale reduction on electric heaters. Energy 77 271-278.

GOPALAN R, ANAND A and SUGUMAR RW (2008) A Laboratory Manual for Environmental Chemistry. I.K. International Publishing House Pvt. Ltd, New Delhi. 191 pp.

GOUWS R and LE ROUX E (2012) Efficiency and cost analysis of a designed in-line water heating system compared to a conventional water heating system in South Africa. J. Energ. South. Afr. 23 (3) 9-15.

HASSON D, SIDORENKO $\mathbf{g}$ and SEMIAT R (2010) Calcium carbonate hardness removal by a novel electrochemical seeds system. Desalination 236 (1-3) 285-289. https://doi.org/10.1016/j. desal.2010.06.036

IBRAHIM O, FARDOUN F, YOUNES R and LOUAHLIA-GUALOUS $\mathrm{H}$ (2014) Review of water-heating systems: General selection approach based on energy and environmental aspects. Build. Environ. 72 259-286. https://doi.org/10.1016/j.buildenv.2013.09.006

RAS HS and GHIZELLAOUI S (2012) Determination of anti-scale effect of hard water by test of electrodeposition. Proc. Eng. 33 357365. https://doi.org/10.1016/j.proeng.2012.01.1215

REIF JH and ALHALABI W (2015) Solar-thermal powered desalination: Its significant challenges and potential. Renew. Sustainable
Energ. Rev. 48 152-165. https://doi.org/10.1016/j.rser.2015.03.065 SAIFELNASR A, BAKHEIT M, KAMAL K and LILA A (2013) Calcium carbonate scale formation, prediction and treatment (Case study Gumry Oilfield - PDOC). Int. Lett. Chem. Phys. Astron. 12 47-58. https://doi.org/10.18052/www.scipress.com/ILCPA.17.47

SENGUPTA P (2013) Potential health impacts of hard water. Int. J. Prev. Med. 4 (8) 866-875.

SHAMS M, MOHAMADI A and SAJADI SA (2012) Evaluation of corrosion and scaling potential of water in rural water supply distribution networks of Tabas, Iran. World Appl. Sci. J. 17 (11) 1484-1489.

SKOOG DA, WEST DM, HOLLER FJ and CROUCH SR (2014) Fundamentals of Analytical Chemistry ( $9^{\text {th }}$ edn). Brooks/Cole Cengage Learning, Belmont USA. 436 pp.

STICKFORD GH Jr. and JOHNSON OD (1984) The effect of hardwater scale buildup on water heater life-cycle efficiency, Gas Research Institute, Battelle Columbus, Ohio, United States. E238-E251.

WIDDER SH and BAECHLER MC (November 2013) Impacts of water quality on residential water heating equipment. Battelle Pacific Northwest National Laboratory, Richland, Washington 99352, PNNL-22921, 1.1-4.3.

\section{APPENDIX A}

\begin{tabular}{|l|c|c|}
\hline \multicolumn{3}{|c|}{ TABLE A1 } \\
\multicolumn{2}{|c|}{ Water analysis: tap water } \\
\hline Chemical parameter & Unit & Value \\
\hline Alkalinity total & $\mathrm{mg} / \mathrm{L} \mathrm{CaCO}$ & 77.83 \\
\hline Calcium as $\mathrm{Ca}$ & $\mathrm{mg} / \mathrm{L}$ & 24 \\
\hline Magnesium as $\mathrm{Mg}$ & $\mathrm{mg} / \mathrm{L}$ & 6.0 \\
\hline Chloride as $\mathrm{Cl}$ & $\mathrm{mg} / \mathrm{L}$ & 14.20 \\
\hline Sodium as $\mathrm{Na}$ & $\mathrm{mg} / \mathrm{L}$ & 11 \\
\hline pH @ $25^{\circ} \mathrm{C}$ & $\mathrm{mg} / \mathrm{L}$ & 7.48 \\
\hline Sulphate as $\mathrm{SO}_{4}$ & $\mathrm{mg} / \mathrm{L}$ & 17.22 \\
\hline Total dissolved solids as $\mathrm{TDS}$ & $\mathrm{mg} / \mathrm{L}$ & 154.4 \\
\hline Ca hardness as $\mathrm{CaCO}$ & $\mathrm{mg} / \mathrm{L}$ & 59.94 \\
\hline Mg hardness as $\mathrm{CaCO}$ & $\mathrm{mg} / \mathrm{L}$ & 24.69 \\
\hline Total hardness as $\mathrm{CaCO}_{3}$ & $\mathrm{mg} / \mathrm{L}$ & 84.63 \\
\hline Turbidity & $\mathrm{NTU}$ & 1.01 \\
\hline Aluminium as $\mathrm{Al}$ & $\mathrm{mg} / \mathrm{L}$ & $<0.005$ \\
\hline Ammonia as $\mathrm{N}$ & $\mathrm{mg} / \mathrm{L}$ & $<0.005$ \\
\hline Cadmium as $\mathrm{Cd}$ & $\mathrm{mg} / \mathrm{L}$ & $<0.005$ \\
\hline Cyanide as $\mathrm{CN}$ & $\mathrm{mg} / \mathrm{L}$ & $<0.025$ \\
\hline Colour & $\mathrm{Hazen}$ & 9 \\
\hline Conductivity & $\mu \mathrm{H} / \mathrm{cm}$ & 250 \\
\hline Cobalt as $\mathrm{Co}$ & $\mathrm{mg} / \mathrm{L}$ & $<0.005$ \\
\hline Total chromium as $\mathrm{Cr}_{2}$ & $\mathrm{mg} / \mathrm{L}$ & $<0.005$ \\
\hline Iron as Fe & $\mathrm{mg} / \mathrm{L}$ & 0.04 \\
\hline Fluoride as $\mathrm{F}$ & $\mathrm{mg} / \mathrm{L}$ & 0.14 \\
\hline Manganese as $\mathrm{Mn}$ & $\mathrm{mg} / \mathrm{L}$ & $<0.005$ \\
\hline Sodium as $\mathrm{Na}$ & $\mathrm{mg} / \mathrm{L}$ & 11 \\
\hline Nickel as $\mathrm{Ni}$ & $\mathrm{mg} / \mathrm{L}$ & $<0.005$ \\
\hline Nitrite as $\mathrm{NO}{ }_{2}$ & $\mathrm{mg} / \mathrm{L}$ & 0.27 \\
\hline Nitrate as $\mathrm{N}$ & $\mathrm{mg} / \mathrm{L}$ & $<0.010$ \\
\hline Lead as $\mathrm{Pb}$ & & 0.84 \\
\hline
\end{tabular}

